\title{
Resistance of rice genotypes to fall armyworm Spodoptera frugiperda (Lepidoptera: Noctuidae)
}

\author{
Cinthia Luzia Teixeira Silva ${ }^{1}$ (D), Fernanda Correa ${ }^{1}$, André Cirilo de Sousa Almeida ${ }^{2}$ (D), \\ Márcio da Silva Araújo ${ }^{1}$ (D), José Alexandre de Freitas Barrigossi ${ }^{3}$ (D), \\ Flávio Gonçalves de Jesus²*
}

${ }^{1}$ Universidade Estadual de Goiás, Campus de Ipameri, Ipameri, GO, Brasil.

Instituto Federal Goiano, Campus Urutaí, Urutaí, GO, Brasil.

${ }^{3}$ Embrapa Arroz e Feijão, Santo Antônio de Goiás, GO, Brasil.

\section{A R T I C L E I N F O}

\section{Article history:}

Received 23 February 2021

Accepted 20 September 2021

Available online 18 October 2021

Associate Editor: Ricardo Siqueira da Silva

\section{Keywords:}

Oryza sativa

Host plant resistance

Antixenosis

Antibiosis

\begin{abstract}
A B S T R A C T
The fall armyworm, Spodoptera frugiperda (J. E. Smith) (Lepidoptera: Noctuidae), is an important rice pest which consumes leaf area during all phases of plant development. The objective of this study was to identify rice genotypes that provide antixenosis and antibiosis to fall armyworm. Antixenosis was investigated by measuring non-preference in free-choice and no-choice tests while antibiosis was determined by measuring biological parameters and nutritional indices of $S$. frugiperda in twelve rice genotypes. The genotype Miúdo Branco showed antixenosis to $S$. frugiperda, whereas the genotypes IR 64 and Bacaba Branco showed antibiosis to S. frugiperda by affecting insect development and prolonging insect life cycle. Insects that fed on Bacaba Branco genotype demonstrated the lowest nutritional indices. Since Miúdo Branco, IR 64 and Bacaba Branco showed moderate resistance, rice producers could use these genotypes as part of a control strategy for S. frugiperda.
\end{abstract}

\section{Introduction}

Rice (Oryza sativa L.) is an important cereal that feeds a significant part of the world population (Stout et al., 2009). Rice yield and quality are severely affected by insect pests (Jiang et al., 2014). The fall armyworm, Spodoptera frugiperda (J.E. Smith) (Lepidoptera: Noctuidae) is native to tropical and subtropical America; however, it has spread rapidly to other continents, and became an invasive pest in African countries in 2016 (Goergen et al., 2016) and has since been confirmed in Asian countries such as India (Mallapur et al., 2018) and China (Jing et al., 2020). Consequently, it is considered one of the most important agricultural pests in the world (Wang et al., 2020). Spodoptera frugiperda is a polyphagous pest that feeds on as many as 353 plant species and is a key pest in maize, rice, sorghum, cotton, and sugarcane (Montezano et al., 2018).

Spodoptera frugiperda is a sporadic pest in rice fields that mainly appears during the early season in unflooded systems (Kraus and

\footnotetext{
* Corresponding author.

E-mail: flavio.jesus@ifgoiano.edu.br (F.G. Jesus).
}

Stout, 2019). The pest damages rice crops by destroying or weakening new plants, cutting culms to the ground, defoliating and damaging flowers and panicles and severely injuring small seedlings that may necessitate replanting (Busato et al., 2005; Nascimento et al., 2014; Kraus and Stout, 2019).

The main methods for controlling $S$. frugiperda in rice crops are synthetic insecticides (Busato et al., 2006). Nevertheless, alternative methods can be used such as flooding the rice crop (flooded systems), increasing natural agents such as parasitoids and predators, applications of Beauveria bassiana as a biological insecticide and applications of insecticidal proteins produced by Bacillus thuringiensis (Barrigossi and Martins, 2015).

Excessive use of chemical insecticides has selected resistant S. frugiperda that have become a significant challenge to integrated pest management - IPM (Bernardi et al., 2016; Viteri et al., 2018). In addition, pesticides add toxic residues to food crops, eliminate natural enemies, may bring about pest resurgence, present risks to the applicator, 
cause environmental contamination and increase costs associated with repeated applications (Bueno et al., 2010; Negrisoli et al., 2010).

Among the alternative control methods that have been studied, plant resistance to insects - PRI has become an important component of IPM in rice (Correa et al., 2018; Almeida et al., 2020; Almeida et al., 2021). PRI is compatible with other control tactics, such as biological control, cultural practices and chemical control, and can minimize insecticide use (Kartohardjono and Heinrichs, 1984; Rashid et al., 2005). PRI keeps pest populations below economic thresholds and does not adversely affect the environment or entail additional costs (Smith and Clement, 2012; Seifi et al., 2013; Ta-Liao and Chen, 2017).

There are three types of PRI: antixenosis, antibiosis and tolerance (Paiva et al., 2018). Antixenosis occurs when insects reduce feeding, oviposition, or shelter in a genotype (Queiroz et al., 2020). Antibiosis negatively affects an insect's biology/physiology by reducing weight, increasing mortality, prolonging life cycle, and reducing fertility (Smith and Clement, 2012; Seifi et al., 2013). Tolerance reflects a plant's ability to recover from insect damage by producing new vegetative or reproductive structures (Smith, 2005; Baldin et al., 2019).

Screening of resistant rice genotypes has become an important component of IPM. Nevertheless, pest resistance in the rice genotypes of Brazil is limited and has only been identified for the stalk borer Diatraea saccharalis Fabricius (Lepidoptera: Crambidae) and rice stalk stink bug Tibraca limbaventris Stål (Hemiptera: Pentatomidae) (Nascimento and Barrigossi, 2014; Nascimento et al., 2015; Correa et al., 2018; França et al., 2018; Almeida et al., 2020). There are currently no rice genotypes that are characterized as resistant to $S$. frugiperda.

The genotype Ku 94-2 showed antibiosis to D. saccharalis due to high larval mortality, while BR IRGA 417, MTU 15 and IR 40 showed tolerance due to greater tiller production in plants damaged by D. saccharalis (Nascimento and Barrigossi, 2014; Nascimento et al., 2015). The cultivars Bonança, Caripuna, IR 42, Canela de Ferro, SWA Norte, BR IRGA 409, Pepita, Serra Dourada, Araguaia, Xingú, Tangará, and Soberana showed antibiosis and/or antixenosis to D. saccharalis (Correa et al., 2018).

The objective of this study was to identify resistance in rice genotypes by antixenosis (non-preference) and antibiosis (biological parameters and nutritional indices) to S. frugiperda.

\section{Material and methods}

Spodoptera frugiperda colony

The experiments were conducted at the Integrated Pest Management Laboratory of the Goiano Federal Institute, Urutaí Campus (Urutaí, GO,
Brazil). The $S$. frugiperda colony was established using caterpillars obtained from the Laboratory of Plant Resistance to Insects at UNESP, Jaboticabal, SP, Brazil.

The pupae were sexed and separated into couples (15 males and 15 females) and kept in polyvinyl chloride (PVC) cages $(15 \mathrm{~cm}$ diameter $\times 20 \mathrm{~cm}$ height) for emergence and adult mating. The cages were lined with paper that served as an oviposition substrate. Adults were fed a $10 \%$ honey solution containing methylparaben and vitamins (Armes et al., 1992) and kept in the same PVC cages.

Spodoptera frugiperda eggs were collected and transferred to plastic pots ( $14 \mathrm{~cm}$ in diameter and $9 \mathrm{~cm}$ height) until larval hatching. Second instar caterpillars were then placed individually in B16 PET trays (CM\&CM Comercio de Plásticos, São Paulo, SP, Brazil) and fed an artificial diet (Greene et al., 1976) until the pupal phase.

The insects were maintained under controlled conditions $\left(25 \pm 2^{\circ} \mathrm{C}\right.$, $70 \pm 10 \%$ relative humidity, and a $12: 12 \mathrm{~h}$ light/dark photoperiod) during all phases of development.

\section{Plant material}

The rice genotypes were obtained from the active gene bank of the Brazilian Agricultural Research Corporation - Embrapa, National Research Center for Rice and Beans (Santo Antônio de Goiás, GO, Brazil) (Table 1). These genotypes were chosen based on historical resistance to different rice pests from different geographic regions and their potential as sources of resistance to S. frugiperda (Correa et al., 2018; Almeida et al., 2020).

The seeds were sown in containers $(3.5 \mathrm{~cm}$ in diameter by $14 \mathrm{~cm}$ in depth) with a substrate (3:1 - soil and sand) and kept in a greenhouse under natural light and temperature conditions. The soil was chemically amended and fertilized as recommended for rice cultivation (Sousa and Lobato, 2004) and irrigated daily at field soil levels. The rice plants used in the experiment were 45 days old. The plants were selected at the end of tillering since pest damage to rice crops is greatest at this critical stage (Barrigossi and Martins, 2015).

\section{Non-preference for feeding and preference index}

In the free-choice test, a perforated polystyrene plate (arena) containing equidistantly distributed whole rice plants was placed in a plastic cage ( $14 \mathrm{~cm} \emptyset \times 20 \mathrm{~cm}$ high and $32 \mathrm{~L} \mathrm{vol}$.) and covered with voile fabric. Twelve $S$. frugiperda larvae (3rd instar) were released in the center of each arena and non-preference was determined by counting the number of insects feeding on each genotype at $1,3,5,10,15,30$,

Table 1

Rice accessions screened for resistance to Spodoptera frugiperda (J. E. Smith, 1797) (Lepidoptera: Noctuidae). Urutaí, GO, Brazil.

\begin{tabular}{|c|c|c|c|}
\hline Genotypes & ID no. & Colletion & Origin \\
\hline Pela Mão & BGA 012512 & Traditional variety & Brasil-Região Nordeste-Maranhão-Lima Campos \\
\hline Gojobinho & BGA 011304 & Traditional variety & Brasil-Região Nordeste -Maranhão-Caxias \\
\hline Lageado Ligeiro & BGA 011384 & Traditional variety & Brasil-Região Nordeste-Maranhão-Tuntum \\
\hline IR 64 & BGA 018794 & Breeding line & Filipinas-Luzon \\
\hline Guabirú & BGA 011324 & Traditional variety & Brasil-Região Nordeste-Maranhão-Caxias \\
\hline Miúdo Branco & BGA 012626 & Traditional variety & Brasil-Região Nordeste-Maranhão-Esperantinópolis \\
\hline Arroz do Governo & BGA 011335 & Traditional variety & Brasil-Região Nordeste-Maranhão-São João do Soter \\
\hline Branco Tardão & BGA 011318 & Traditional variety & Brasil-Região Nordeste-Maranhão-Caxias \\
\hline Nenenzinho & BGA 011585 & Traditional variety & Brasil-Região Nordeste-Maranhão \\
\hline Trinca Ferro & BGA 011391 & Traditional variety & Brasil-Região Nordeste-Maranhão-Presidente Dutra \\
\hline Bacaba Branco & BGA 011352 & Traditional variety & Brasil-Região Nordeste-Maranhão-Timbira \\
\hline Bico Ganga & BGA 000412 & Traditional variety & Brasil \\
\hline
\end{tabular}


$60,120,360,720$ and $1440 \mathrm{~min}$. A mean reference value was calculated from all evaluation times. The data were generated from a randomized block design with 12 treatments (genotypes) and 10 replicates (arenas).

In the no-choice test, 20 rice plants from each genotype were grown individually in containers ( $3.5 \mathrm{~cm}$ in diameter by $14 \mathrm{~cm}$ in depth) and infested with one larvae of $S$. frugiperda (3rd instar). The containers were arranged in a plastic tray $(38 \mathrm{~cm} \times 58 \mathrm{~cm})$ and maintained under laboratory conditions at $25 \pm 2{ }^{\circ} \mathrm{C}, 60 \pm 10 \% \mathrm{RH}$, and $12: 12 \mathrm{~h}$ (L:D). The number of insects feeding on each genotype was recorded at the same intervals used in the free-choice test. The data were generated from a completely randomized design with 12 treatments (genotypes) and 20 replicates (pots).

The preference index (AI) was calculated according to Kogan and Goeden (1970) with the following formula: $\mathrm{AI}=2 \mathrm{C} /(\mathrm{C}+\mathrm{S})$, where $\mathrm{C}=$ the number of insects attracted to a given genotype and $\mathrm{S}=$ the number of insects attracted to the standard susceptible genotype (Guabirú - BGA 011324). The standard susceptible genotype was obtained from the average number of larvae attracted to the genotypes at all assessment times.

\section{Biological parameters and nutritional indices}

Antibiosis was measured for each newly hatched $S$. frugiperda larva, which were kept in individual cells $(5.5 \mathrm{~cm} \times 3.5 \mathrm{~cm}$ and $2 \mathrm{~cm}$ height) of a plastic tray $(27.5 \mathrm{~cm}$ x $20 \mathrm{~cm})$ (CM \& CM Comercio de Plásticos, Pinheiros, SP, Brazil) containing moistened filter paper and fed with leaves from the rice genotypes. The larvae remained in the plastic container until the pupal stage when feeding was interrupted.

The emerged adults were separated and caged to measure longevity without feeding. The following biological parameters were evaluated: a) larval phase: duration and viability of the larval stage and weight of larvae at 10 days; b) pre-pupal phase: duration and viability; c) pupal stage: duration, weight of pupa after 24 hours and viability; d) adult: longevity and sex ratio, and e) total cycle: period and viability. Each replication (a single larva in a plastic container) was set up in a completely randomized design with 12 treatments (genotypes) and 32 replicates.

After abstaining from food for 3 hours, a separate group of $S$. frugiperda larvae (3rd instar) were weighed and then segregated in petri dishes $(1.5 \times 9.0 \mathrm{~cm}$ diameter $)$ that were lined with moistened filter paper and supplied with leaf tissue from each genotype for 7 days. The leaf sections were replaced daily. After 7 days, the feces and remaining unconsumed leaf sections were separated and dried in an oven (Nova Ética, Vargem Grande Paulista, SP, Brazil) at $60^{\circ} \mathrm{C}$ for $48 \mathrm{~h}$ and weighed on an analytic scale (Marter, Santa Rita do Sapucaí, MG, Brazil). The dry weights were used to calculate the nutritional indices.

The following nutritional indices were determined according to Waldbauer (1968) and Scriber and Slansky Junior (1981): relative consumption rate (RCR; $\mathrm{g} / \mathrm{g} / \mathrm{d})$, relative metabolic rate $(R M R=\mathrm{M} / \mathrm{Bm}$ by $\mathrm{T} ; \mathrm{g} / \mathrm{g} / \mathrm{d})$, relative growth rate $(\mathrm{RGR}=\mathrm{B} / \mathrm{Bm}$ by $\mathrm{T} ; \mathrm{g} / \mathrm{g} / \mathrm{d})$, conversion efficiency of ingested food $(E C I=[B / I] \times 100 ; \%)$, conversion efficiency of digested food $(E C D=B /[I-F] \times 100 ; \%)$, and approximate digestibility $(\mathrm{AD}=[\mathrm{I}-\mathrm{F}] / \mathrm{I} \times 100 ; \%)$, where $\mathrm{T}=$ feeding period, $\mathrm{I}=$ food consumption during $\mathrm{T}, \mathrm{B}=$ larval weight gain during $\mathrm{T}, \mathrm{F}=$ feces produced during $\mathrm{T}$, $M=$ food used in metabolic processes during $T(M=[I-F]-B)$, and $\mathrm{Bm}=$ mean larval weight during $\mathrm{T}$. The experiment was conducted in a completely randomized design with 12 treatments and 10 replicates.

\section{Statistical analysis}

An analysis of variance model was fit to the data from each experiment. Residual normality and homoscedasticity were determined by the Shapiro-Wilk and Bartlett tests. When data did not meet these assumptions, the Box-Cox method was used to find an optimal transformation. The transformed data were then used to fit the analysis of variance models and the means were compared by the Scott-Knott test $(\alpha=0.05)$ (R Core Team 2017 - ScottKnott package). The means were back transformed for presentation purposes. Hierarchical Cluster Analysis - UPGMA (based on the Euclidian distance) was used to determine resistance patterns among the rice genotypes ( $R$ Core Team 2017 - biotools package). The preference index (AI) and standard error for each genotype were calculated and then compared to 1.0 (neutral susceptible genotype - Guabirú - BGA 011324) using the Student's t test $(\alpha=0.05)$. The genotypes that presented indices statistically different from 1.0 were classified as either deterrent $(<1.0)$ or stimulating $(>1.0)$.

\section{Results}

The free-choice test showed no significant differences among rice genotypes regarding non-preference to Spodoptera frugiperda $(\mathrm{F}=1.03$; $\mathrm{df}=11 ; \mathrm{P}=0.4283)$. According to the preference indexes, the genotypes Pela Mão (0.56; $\mathrm{P}=0.0688)$, Lageado Ligeiro (0.42; $\mathrm{P}=0.0166)$, Miúdo Branco (0.60; $\mathrm{P}=0.0231)$, and Branco Tardão $(0.50 ; \mathrm{P}=0.0408)$ were the most preferred by $S$. frugiperda (Table 2 ).

Table 2

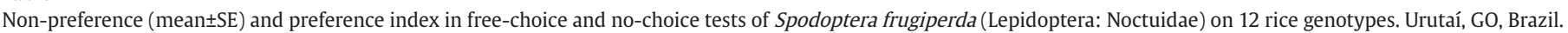

\begin{tabular}{|c|c|c|c|c|}
\hline \multirow{2}{*}{ Genotypes* } & \multicolumn{2}{|c|}{ Free-choice test } & \multicolumn{2}{|c|}{ No-choice test } \\
\hline & Preference & Index (P value) & Preference & Index (P value) \\
\hline Pela Mão & $0.22 \pm 0.07$ & $0.56(0.0688)$ & $0.77 \pm 0.04 a$ & $1.08(0.4983)$ \\
\hline Gojobinho & $0.40 \pm 0.18$ & $1.14(0.1388)$ & $0.80 \pm 0.06 a$ & $1.11(0.1490)$ \\
\hline Lageado Ligeiro & $0.25 \pm 0.06$ & $0.42(0.0166)$ & $0.62 \pm 0.06 a$ & 0.95 (0.8099) \\
\hline IR 64 & $0.47 \pm 0.16$ & $1.01(0.9452)$ & $0.71 \pm 0.04 a$ & $1.04(0.6729)$ \\
\hline Guabirú & $0.30 \pm 0.09$ & 1.00 & $0.69 \pm 0.05 a$ & 1.00 \\
\hline Miúdo Branco & $0.18 \pm 0.06$ & $0.60(0.0231)$ & $0.47 \pm 0.08 \mathrm{~b}$ & $0.85(0.1575)$ \\
\hline Arroz do Governo & $0.22 \pm 0.07$ & $0.67(0.1484)$ & $0.49 \pm 0.06 b$ & $0.85(0.2514)$ \\
\hline Branco Tardão & $0.32 \pm 0.16$ & $0.50(0.0408)$ & $0.64 \pm 0.06 a$ & $0.96(0.9468)$ \\
\hline Nenenzinho & $0.17 \pm 0.06$ & $0.68(0.1287)$ & $0.50 \pm 0.05 b$ & $0.84(0.2075)$ \\
\hline Trinca Ferro & $0.26 \pm 0.08$ & $0.83(0.4306)$ & $0.70 \pm 0.05 a$ & $1.02(0.6544)$ \\
\hline Bacaba Branco & $0.56 \pm 0.08$ & $1.07(0.7434)$ & $0.67 \pm 0.06 a$ & $0.99(0.7996)$ \\
\hline Bico Ganga & $0.47 \pm 0.10$ & $1.23(0.1408)$ & $0.72 \pm 0.07 a$ & $1.02(0.5547)$ \\
\hline F treatments & 1.03 & - & 2.97 & - \\
\hline$P$ value & 0.4283 & - & 0.0017 & - \\
\hline
\end{tabular}

${ }^{*}$ Means followed by the same letter do not differ statistically according to the Scott-Knott test at 5\% probability. 
The no-choice test showed that $S$. frugiperda was least attracted to Miúdo Branco (0.47), Arroz do Governo (0.49) and Nenenzinho (0.50). The other genotypes were equally more attractive. The preference index from the non-choice test showed no significant differences among rice genotypes relative to the standard susceptible genotype - Guabirú (Table 2).

Spodoptera frugiperda development was influenced by the rice genotypes. The larval period was longest $(\mathrm{F}=13.47 ; \mathrm{df}=11 ; \mathrm{P}<0.0001)$ when caterpillars were fed on the IR 64 genotype and shorter for the other genotypes (Table 3 ).

The pre-pupal period was longest in caterpillars fed on IR 64 and Bacaba Branco and shortest in Nenenzinho, Miúdo Branco, Pela Mão and Trinca Ferro $(\mathrm{F}=2.75 ; \mathrm{df}=11 ; \mathrm{P}=0.0002)$. The pupal period was longest for insects feeding on Bacaba Branco and Branco Tardão and shortest in the other genotypes, except Guabirú, IR 64 and Bico Ganga $(\mathrm{F}=1.62 ; \mathrm{df}=11 ; \mathrm{P}=0.0562)$.

The longevity of adult $S$. frugiperda was greatest in the genotypes Bico Ganga, Bacaba Branco, Nenenzinho, Branco Tardão, Trinca Ferro, Arroz do Governo and Miúdo Branco and shortest in the remaining genotypes $(\mathrm{F}=3.12 ; \mathrm{df}=11 ; \mathrm{P}<0.0001)$. The total $S$. frugiperda cycle was longest in insects fed on IR 64 and Bacaba Branco and shortest in Pela Mão, Nenenzinho and Gojobinho ( $\mathrm{F}=7.93$; $\mathrm{df}=11 ; \mathrm{P}<0.0001)$.
Spodoptera frugiperda fed on the genotypes Bacaba Branco, Arroz do Governo, Branco Tardão, Trinca Ferro and Nenenzinho showed the lowest total viability $(\mathrm{F}=19.14 ; \mathrm{df}=11 ; \mathrm{P}<0.0001)$.

The nutritional indices of $S$. frugiperda were influenced by the rice genotypes (Table 4 and Table 5). Consumption was lowest in Bico Ganga, Bacaba Branco, Arroz do Governo, Gojobinho, Branco Tardão, Nenenzinho, Guabirú, Lageado Ligeiro and Miúdo Branco genotypes $(\mathrm{F}=9.31 ; \mathrm{df}=11 ; \mathrm{P}<0.0001)$. Larval weight gain was highest in Pela Mão $(\mathrm{F}=7.71 ; \mathrm{df}=11 ; \mathrm{P}<0.0001)$ and lowest in the remaining 11 rice genotypes. The lowest RCR was observed in the genotypes Miúdo Branco, Arroz do Governo, Branco Tardão, Bico Ganga, Gojobinho, Pela Mão and Bacaba Branco ( $\mathrm{F}=3.37$; $\mathrm{df}=11 ; \mathrm{P}<0.0001)$. The lowest RMR values were found in Arroz do Governo, Gojobinho, Miúdo Branco, Lageado Ligeiro, Bico Ganga, Pela Mão, Nenenzinho and Bacaba Branco ( $F=2.95$; $\mathrm{df}=11 ; \mathrm{P}=0.0002)$. The remaining genotypes provided the lowest RGR values, except Pela Mão ( $F=5.99 ; \mathrm{df}=11 ; \mathrm{P}<0.0001)$ (Table 4).

The AD of $S$. frugiperda was lowest in Arroz do Governo, Gojobinho, Nenenzinho, Lageado Ligeiro and Trinca Ferro $(\mathrm{F}=6.18$; $\mathrm{df}=11$; $\mathrm{P}<0.0001$ ), while ECI was lowest in Nenenzinho, Trinca Ferro and Guabirú ( $\mathrm{F}=3.53$; df = 11.108; P <0.0001). ECD was lowest in IR 64, Guabirú, Trinca Ferro, Branco Tardão, Nenenzinho and Bacaba Branco $(\mathrm{F}=2.70 ; \mathrm{df}=11 ; \mathrm{P}=0.0042)$ and $\mathrm{MC}$ was lowest in Arroz do Governo,

Table 3

Duration (mean \pm SE) of the larval, pre-pupal and pupal periods (days), adult longevity (days), total cycle (days) and total viability (\%) of Spodoptera frugiperda (Lepidoptera: Noctuidae) on 12 rice genotypes. Urutaí, GO, Brazil.

\begin{tabular}{|c|c|c|c|c|c|c|}
\hline Genotypes* & Larval & Pre-pupal & Pupal & Longevity & Total cycle & Viability \\
\hline Pela Mão & $19.50 \pm 0.19 b$ & $1.28 \pm 0.11 \mathrm{c}$ & $13.00 \pm 0.19 c$ & $4.75 \pm 0.21 b$ & $38.53 \pm 0.35 d$ & $98.12 \pm 6.5 a$ \\
\hline Gojobinho & $20.36 \pm 0.41 b$ & $1.43 \pm 0.13 b$ & $12.85 \pm 0.34 c$ & $4.59 \pm 0.19 b$ & $39.00 \pm 0.60 d$ & $84.37 \pm 6.2 \mathrm{a}$ \\
\hline Lageado Ligeiro & $20.72 \pm 0.58 b$ & $1.48 \pm 0.24 b$ & $13.11 \pm 0.51 c$ & $4.77 \pm 0.68 b$ & $39.88 \pm 1.40 c$ & $84.37 \pm 8.7 a$ \\
\hline IR 64 & $24.10 \pm 0.77 a$ & $1.70 \pm 0.22 \mathrm{a}$ & $13.57 \pm 0.71 b$ & $4.65 \pm 0.21 b$ & $43.00 \pm 1.26 a$ & $81.25 \pm 7.4 a$ \\
\hline Guabirú & $20.74 \pm 0.29 b$ & $1.51 \pm 0.14 b$ & $13.64 \pm 0.23 b$ & $4.80 \pm 0.39 b$ & $40.52 \pm 0.54 b$ & $78.12 \pm 6.5 a$ \\
\hline Miúdo Branco & $19.59 \pm 0.39 b$ & $1.09 \pm 0.11 c$ & $13.14 \pm 0.19 c$ & $5.71 \pm 0.22 \mathrm{a}$ & $39.57 \pm 0.45 c$ & $65.62 \pm 7.4 \mathrm{~b}$ \\
\hline Arroz do Governo & $19.28 \pm 0.28 b$ & $1.50 \pm 0.09 b$ & $12.60 \pm 0.23 c$ & $5.60 \pm 0.20 \mathrm{a}$ & $39.60 \pm 0.45 c$ & $15.62 \pm 6.4 \mathrm{c}$ \\
\hline Branco Tardão & $20.00 \pm 0.29 b$ & $1.50 \pm 0.10 \mathrm{~b}$ & $14.33 \pm 0.15 a$ & $5.33 \pm 0.15 a$ & $41.00 \pm 0.39 b$ & $18.75 \pm 6.2 c$ \\
\hline Nenenzinho & $18.75 \pm 0.36 b$ & $1.00 \pm 0.27 c$ & $13.45 \pm 0.26 c$ & $5.27 \pm 0.26 \mathrm{a}$ & $38.54 \pm 0.55 d$ & $34.37 \pm 6.5 c$ \\
\hline Trinca Ferro & $20.10 \pm 0.29 b$ & $1.33 \pm 0.06 c$ & $13.33 \pm 0.18 c$ & $5.44 \pm 0.18 \mathrm{a}$ & $39.88 \pm 0.38 c$ & $28.12 \pm 6.8 \mathrm{c}$ \\
\hline Bacaba Branco & $21.66 \pm 0.19 b$ & $1.80 \pm 0.10 \mathrm{a}$ & $14.20 \pm 0.38 a$ & $5.20 \pm 0.38 a$ & $42.80 \pm 0.38 a$ & $15.62 \pm 7.2 \mathrm{c}$ \\
\hline Bico Ganga & $20.36 \pm 0.47 b$ & $1.54 \pm 0.15 b$ & $13.70 \pm 0.16 b$ & $5.15 \pm 0.16 a$ & $40.55 \pm 0.60 b$ & $62.50 \pm 7.0 \mathrm{~b}$ \\
\hline F treatments & 13.47 & 2.75 & 1.62 & 3.12 & 7.93 & 19.14 \\
\hline$P$ value & $<0.0001$ & 0.0002 & 0.0562 & $<0.0001$ & $<0.0001$ & $<0.0001$ \\
\hline
\end{tabular}

${ }^{*}$ Means followed by the same letter do not differ statistically according to the Scott-Knott test at 5\% probability.

Table 4

Nutritional indices (meanıstandard error) of Spodoptera frugiperda (Lepidoptera: Noctuidae) fed on 12 rice genotypes. Urutaí, GO, Brazil.

\begin{tabular}{|c|c|c|c|c|c|}
\hline Genotypes* & Consumption & Weight gain & RCR & RMR & RGR \\
\hline Pela Mão & $0.171 \pm 0.004 a$ & $0.030 \pm 0.001 a$ & $1.25 \pm 0.06 b$ & $0.29 \pm 0.02 b$ & $0.22 \pm 0.00 \mathrm{a}$ \\
\hline Gojobinho & $0.117 \pm 0.017 c$ & $0.017 \pm 0.002 b$ & $1.24 \pm 0.07 b$ & $0.22 \pm 0.02 b$ & $0.17 \pm 0.01 b$ \\
\hline Lageado Ligeiro & $0.128 \pm 0.007 c$ & $0.018 \pm 0.001 b$ & $1.37 \pm 0.10 \mathrm{a}$ & $0.27 \pm 0.05 b$ & $0.19 \pm 0.01 b$ \\
\hline IR 64 & $0.138 \pm 0.006 \mathrm{~b}$ & $0.020 \pm 0.000 \mathrm{~b}$ & $1.35 \pm 0.07 a$ & $0.43 \pm 0.05 a$ & $0.20 \pm 0.01 b$ \\
\hline Guabirú & $0.124 \pm 0.006 c$ & $0.016 \pm 0.002 b$ & $1.39 \pm 0.05 a$ & $0.37 \pm 0.05 a$ & $0.17 \pm 0.01 b$ \\
\hline Miúdo Branco & $0.130 \pm 0.006 c$ & $0.022 \pm 0.002 b$ & $1.17 \pm 0.07 b$ & $0.26 \pm 0.03 b$ & $0.18 \pm 0.01 b$ \\
\hline Arroz do Governo & $0.111 \pm 0.005 c$ & $0.017 \pm 0.001 b$ & $1.22 \pm 0.09 \mathrm{~b}$ & $0.21 \pm 0.04 b$ & $0.18 \pm 0.01 b$ \\
\hline Branco Tardão & $0.118 \pm 0.004 c$ & $0.018 \pm 0.001 b$ & $1.22 \pm 0.03 b$ & $0.34 \pm 0.02 a$ & $0.18 \pm 0.01 b$ \\
\hline Nenenzinho & $0.120 \pm 0.004 \mathrm{c}$ & $0.012 \pm 0.000 \mathrm{~b}$ & $1.59 \pm 0.07 a$ & $0.29 \pm 0.03 b$ & $0.16 \pm 0.00 \mathrm{~b}$ \\
\hline Trinca Ferro & $0.137 \pm 0.007 b$ & $0.017 \pm 0.001 b$ & $1.46 \pm 0.07 a$ & $0.34 \pm 0.03 a$ & $0.17 \pm 0.01 b$ \\
\hline Bacaba Branco & $0.110 \pm 0.004 c$ & $0.016 \pm 0.001 b$ & $1.25 \pm 0.06 b$ & $0.30 \pm 0.02 b$ & $0.17 \pm 0.01 b$ \\
\hline Bico Ganga & $0.101 \pm 0.005 c$ & $0.015 \pm 0.000 \mathrm{~b}$ & $1.23 \pm 0.03 b$ & $0.27 \pm 0.03 \mathrm{~b}$ & $0.18 \pm 0.01 b$ \\
\hline$F$ treatment & 9.37 & 7.71 & 3.37 & 2.95 & 5.99 \\
\hline P value & $<0.0001$ & $<0.0001$ & $<0.0001$ & 0.0002 & $<0.0001$ \\
\hline
\end{tabular}

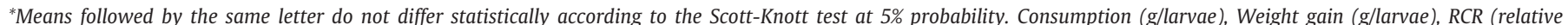
consumption rate - $\mathrm{g} / \mathrm{g} / \mathrm{d}$ ), RMR (relative metabolic rate $-\mathrm{g} / \mathrm{g} / \mathrm{d}$ ), $R G R$ (relative growth rate $-\mathrm{g} / \mathrm{g} / \mathrm{d}$ ). 
Table 5

Nutritional indices (mean \pm standard error) of Spodoptera frugiperda (Lepidoptera: Noctuidae) fed on 12 rice genotypes. Urutaí, GO, Brazil.

\begin{tabular}{|c|c|c|c|c|}
\hline Genotypes* & $\mathrm{AD}(\%)$ & $\mathrm{ECI}(\%)$ & ECD (\%) & MC (\%) \\
\hline Pela Mão & $41.46 \pm 1.94 a$ & $17.90 \pm 0.84 a$ & $43.61 \pm 2.07 a$ & $56.38 \pm 2.07 b$ \\
\hline Gojobinho & $32.61 \pm 1.11 b$ & $14.85 \pm 1.41 \mathrm{a}$ & $45.29 \pm 3.19 a$ & $54.70 \pm 3.19 b$ \\
\hline Lageado Ligeiro & $34.74 \pm 2.11 b$ & $15.14 \pm 1.75 a$ & $44.70 \pm 5.08 \mathrm{a}$ & $55.29 \pm 5.08 b$ \\
\hline IR 64 & $45.77 \pm 1.75 a$ & $14.76 \pm 0.94 a$ & $32.90 \pm 2.92 b$ & $67.09 \pm 2.92 \mathrm{a}$ \\
\hline Guabirú & $39.82 \pm 2.75 a$ & $12.95 \pm 1.02 b$ & $33.69 \pm 2.94 b$ & $66.30 \pm 2.94 \mathrm{a}$ \\
\hline Miúdo Branco & $38.82 \pm 1.82 \mathrm{a}$ & $16.63 \pm 1.57 a$ & $42.66 \pm 3.25 a$ & $57.32 \pm 3.25 b$ \\
\hline Arroz do Governo & $32.60 \pm 1.96 \mathrm{~b}$ & $15.45 \pm 1.21 \mathrm{a}$ & $48.69 \pm 4.43 a$ & $51.30 \pm 4.43 b$ \\
\hline Branco Tardão & $43.23 \pm 1.03 a$ & $15.26 \pm 0.76 a$ & $35.35 \pm 1.68 b$ & $64.64 \pm 1.68 a$ \\
\hline Nenenzinho & $28.40 \pm 1.86 b$ & $10.39 \pm 0.50 \mathrm{~b}$ & $37.96 \pm 3.06 \mathrm{~b}$ & $62.03 \pm 3.06 \mathrm{a}$ \\
\hline Trinca Ferro & $35.60 \pm 1.52 b$ & $12.25 \pm 0.73 b$ & $34.68 \pm 2.03 b$ & $65.31 \pm 2.03 a$ \\
\hline Bacaba Branco & $39.16 \pm 2.71 a$ & $14.63 \pm 0.89 a$ & $37.96 \pm 2.02 b$ & $62.03 \pm 2.02 \mathrm{a}$ \\
\hline Bico Ganga & $37.43 \pm 1.60 a$ & $14.84 \pm 0.49 a$ & $40.44 \pm 2.61 \mathrm{a}$ & $59.54 \pm 2.61 b$ \\
\hline F treatment & 6.18 & 3.53 & 2.70 & 2.71 \\
\hline P value & $<0.0001$ & $<0.0001$ & 0.0042 & 0.0043 \\
\hline
\end{tabular}

${ }^{*}$ Means followed by the same letter do not differ statistically according to the Scott-Knott test at 5\% probability. AD (approximate digestibility), ECI (efficiency of conversion of ingested food), ECD (efficiency of conversion of digested food), MC (metabolic cost).

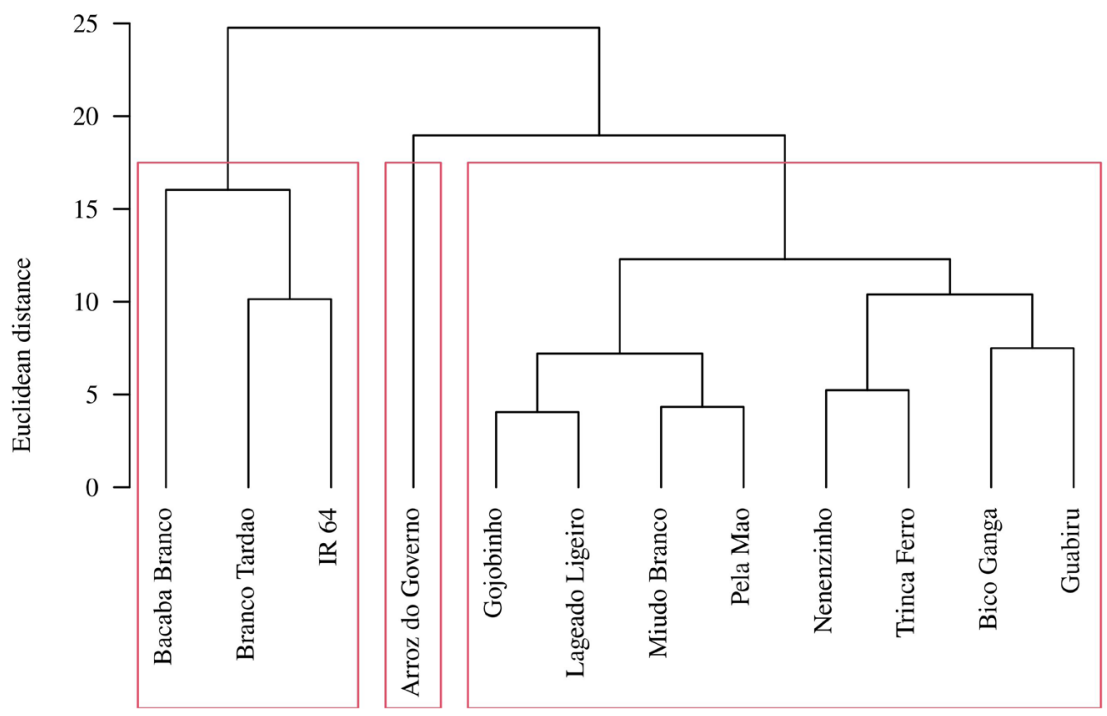

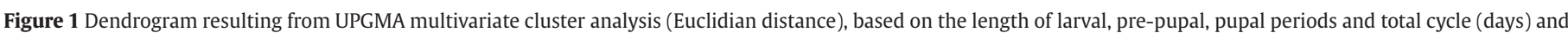

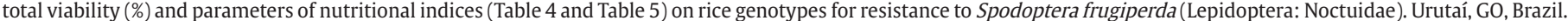

Gojobinho, Lageado Ligeiro, Pela Mão, Miúdo Branco and Bico Ganga $(\mathrm{F}=2.71 ; \mathrm{df}=11 ; \mathrm{P}=0.0043)$.

The rice genotypes were grouped into three resistance levels according to UPGMA (Euclidian distance) (Figure 1). Group I consisted of one susceptible genotype: Arroz do Governo, group II contained moderately resistant genotypes (Bacaba Branco, Branco Tardão and IR 64) and group III had the highly susceptible genotypes Gojobinho, Lageado Ligeiro, Miudo Branco, Pela Mão, Nenenzinho, Trinca Ferro, Bico Ganga and Guabirú.

\section{Discussion}

Resistance to $S$. frugiperda in rice genotypes has been little studied in Brazil. Some studies on rice and S. frugiperda have examined the induction response to silicon and its negative effects on insect biology (Nascimento et al., 2017; França et al., 2018). Other studies have looked at creating resistance to $S$. frugiperda by inserting Bacillus thuringiensis (cry1Aa and cry1B) in rice (Pinto et al., 2013). Thus, selecting for PRI in rice genotypes via classical methods is an important component of IPM in rice crops (Baldin et al., 2019).

Our results showed that the Miúdo Branco genotype exhibited antixenosis to $S$. frugiperda. Antixenosis is related to insect preference for hosts regarding feeding, oviposition and/or shelter. The deterrence attributes of these rice genotypes can be mediated by chemical substances or morphological characteristics of the plants (Smith and Clement, 2012; Seifi et al., 2013; Baldin et al., 2019).

Spodoptera frugiperda biology was negatively affected by feeding on IR 64 and Bacaba Branco (Table 3). Specifically, IR 64 prolonged the larval and pre-pupal phases and overall life cycle of $S$. frugiperda, while Bacaba Branco prolonged insect development (larval and pre-pupal periods and total cycle) and produced lower $S$. frugiperda viability. Longer larval phases suggest inadequate nutrition resulting from chemical compounds that confer insect resistance to the plant (Silva et al., 2017; Almeida et al., 2017).

The lower consumption and nutrition indices (weight gain, RCR, RMR and RGR) of insects fed on Gojobinho, Miúdo Branco, Arroz do Governo, Bacaba Branco and Bico Ganga indicate that these genotypes 
have compounds that may have inhibited the larval development of S. frugiperda.

Antibiosis in Bacaba Branco was indicated by the poor performance of $S$. frugiperda and consequent prolongation of the immature phase of this insect. Usually, reductions in food consumption decrease the size and weight and prolong the life cycle of an insect (Hemati et al., 2012). Plants with allelochemicals and insufficient nutrients can influence insect development. The low RCR levels in the insects feeding on Bacaba Branco may be associated with the presence of allelochemicals or interactions among nutrients and allelochemicals in the plant, suggesting that this genotype may not be a preferred host for S. frugiperda (Ramalho et al., 2011).

Among the rice genotypes with resistance characteristics, IR64, Bacaba Branco and Branco Tardão produced the lowest ECD values. ECD represents the conversion rate of digested food and lower values suggest that $S$. frugiperda larvae spent more time feeding on these genotypes. These results indicate that the IR64, Bacaba Branco and Branco Tardão genotypes probably have metabolic compounds that inhibit the development of $S$. frugiperda.

Multivariate analysis (UPGMA cluster analysis) grouped the rice genotypes by resistance levels, which complemented the results of the univariate analysis (Pitta et al., 2010). This study showed that the IR 64, Bacaba Branco and Branco Tardão genotypes presented resistance characteristics that negatively affected the development of S. frugiperda. The resistant rice genotypes IR 64, Bacaba Branco and Branco Tardão could be incorporated into an IPM strategy for managing $S$. frugiperda.

\section{Acknowledgments}

The authors recognize the Federal Goiano Institute - Campus Urutaí for support and Embrapa Rice and Beans (Santo Antônio de Goiás, Goiás, Brazil) for providing the rice genotypes. This study was partially supported by the National Council of Research and Technology of Brazil (CNPq), grant 406904/2016-2. The University of Goiás State (UEG) Campus Ipameri for the scholarship granted to CLTS.

\section{Conflicts of interest}

The authors declare that they have no conflicts of interest.

\section{Author contribution statement}

This work was carried out in collaboration between the authors. FGJ and CLTS designed and performed the trials with the help of FC, ACSA, MSA and JAFB. FGJ and CLTS analyzed the data and wrote the manuscript. All authors have read and agreed to the published version of the manuscript.

\section{References}

Almeida, A.C.S., Silva, C.L.T., Paiva, L.A., Araújo, M.S., Jesus, F.G., 2017. Antibiosis in soybean cultivars to Heliothis virescens (Lepidoptera: noctuidae). Fla. Entomol. 100, 334-338. https://doi.org/10.1653/024.100.0231.

Almeida, A.C.S., Dierings, C.A., Borella Junior, C., Jesus, F.G., Barrigossi, J.A.F., 2020. Resistance of rice genotypes to Tibraca limbativentris (Hemiptera: pentatomidae). J. Econ. Entomol. 20, 1-7. https://doi. org/10.1093/jee/toz277.

Almeida, A.C.S., Jesus, F.G., Heng-Moss, T.M., Lanna, A.C., Barrigossi, J.A.F., 2021. Evidence for rice tolerance to Tibraca limbativentris
(Hemiptera: pentatomidae). Pest Manag. Sci. 77(9), 4181-4191. https://doi.org/10.1002/ps.6455.

Armes, N.J., Bond, G.S., Cooter, R.J., 1992. The laboratory culture and development of Helicoverpa armigera. Natural Resources Inst. Bull. 57. Natural Resources Institute, Chatham, United Kingdom.

Baldin, E.L.L., Vendramim, J.D., Lourenção, A.L., 2019. Resistência de plantas a insetos: fundamentos e aplicações. FEALQ, Piracicaba, 493 p.

Barrigossi, J.A.F., Martins, J.F., 2015. Manejo de Pragas. In: Borém, A., Rangel, P.H.N (Eds.), Arroz do plantio a colheita. Editora UFV, Viçosa, pp. 178-198.

Bernardi, O., Bernardi, D., Horikoshi, R.J., Okuma, D.M., Miraldo, L.L., Fatoretto, J., Medeiros, F.C.L., Burd, T., Omoto, C., 2016. Selection and characterization of resistance to the Vip3Aa20 protein from Bacillus thuringiensis in Spodoptera frugiperda. Pest Manag. Sci. 72, 1794-1802. https://doi.org/10.1002/ps.4223.

Bueno, R.C.O., Carneiro, T.R., Bueno, A.F., Pratissoli, D., Fernandes, O.A., Vieira, S. S., 2010. Parasitism capacity of Telenomus remus Nixon (Hymenoptera: Scelionidae) on Spodoptera frugiperda (Smith) (Lepidoptera: Noctuidae) eggs. Braz. Arch. Biol. Technol. 53, 133-139. https://doi.org/10.1590/S1516-89132010000100017.

Busato, G.R., Grützmacher, A.D., Garcia, M.S., Zotti, M.J., Nörnberg, S.D., Magalhães, T.R., Magalhães, J.B., 2006. Susceptibilidade de lagartas dos biótipos milho e arroz de Spodoptera frugiperda (J. E. Smith, 1797) (Lepidoptera: Noctuidae) a inseticidas com diferentes modos de ação. Cienc. Rural 36, 15-20. https://doi.org/10.1590/S010384782006000100003.

Busato, G.T., Grützmacher, A.D., Garcia, M.S., Giolo, F.P., Zotti, M.J., Stefanello Júnior, G.J., 2005. Biologia comparada de populações de Spodoptera frugiperda (J. E. Smith) (Lepidoptera: Noctuidae) em folhas de milho e arroz. Neotrop. Entomol. 34, 743-750. https:// doi.org/10.1590/S1519-566X2005000500005.

Correa, F., Silva, C.L.T., Pelosi, A.P., Almeida, A.C.S., Heinrichs, E.A., Barrigossi, J.A.F., Jesus, F.G., 2018. Resistance in 27 rice cultivars to sugarcane borer (Lepidoptera: crambidae). J. Econ. Entomol. 111, 422-427. https://doi.org/10.1093/jee/tox291.

França, L.L., Dierings, C.A., Almeida, A.C.S., Araújo, M.S., Heinrichs, E.A., Silva, A.R., Barrigossi, J.A.F., Jesus, F. G., 2018. Resistance in rice to Tibraca limbaventris (Hemiptera: Pentatomidae) infuenced by plant silicon contente. Fla. Entomol. 101, 587-591. https://doi. org/10.1653/024.101.0419.

Goergen, G., Kumar, P.L., Sankung, S.B., Togola, A., Tamò, M., 2016. First report of outbreaks of the fall armyworm Spodoptera frugiperda (J.E. Smith) (Lepidoptera, Noctuidae), a new alien invasive pest in West and Central Africa. PLoS One 11 (10), e0165632. https://doi. org/10.1371/journal.pone.0165632.

Greene, G.L., Leppla, N.C., Dickerson, W.A., 1976. Velvetbean caterpillar: a rearing procedure and artificial medium. J. Econ. Entomol. 69, 487-488.

Hemati, S.A., Naseri, B., Ganbalani, G.N., Dastjerdi, H.R., Golizadeh, A., 2012. Effect of different host plants on nutritional indices of the Pod Borer, Helicoverpa armigera. J. Insect Sci. 12, 1-15. https://doi. org/10.1673/031.012.5501.

Jiang, L.B., Cheng, J., Zhu, Z.F., Ge, L.Q., Yang, G.Q., Wu, J.C., 2014. Impact of day intervals on sequential infestations of the rice Leaffolder Cnaphalocrocis medinalis (Guenée) (Lepidoptera: Pyralidae) and the white backed rice Planthopper Sogatella furcifera (Horváth) on rice grain damage. Int. J. Insect Sci. 6, 23-31. https://doi.org/10.1177/ IJIS.S13536.

Jing, D., Guo, F., Jiang, Y., Zhao, J., Sethi, A., He, K., Wang, Z., 2020. Initial detections and spread of invasive Spodoptera frugiperda in China and comparisons with other noctuid larvae in cornfields 
using molecular techniques. Insect Sci. 27, 780-790. https://doi. org/10.1111/1744-7917.12700.

Kartohardjono, A., Heinrichs, E.A., 1984. Populations of the brown planthopper, Nilaparvata lugens (Stål) (Homoptera: Delphacidae), and its predators on rice varieties with different levels of resistance. Environ. Entomol. 13, 359-365. https://doi.org/10.1093/ee/13.2.359.

Kogan, M., Goeden, R.D., 1970. The host-plant ranger of Lema trilineata daturaphila (Coleoptera: chrysomelidae). Ann. Entomol. Soc. Am. 63, 1175-1180.

Kraus, E.C., Stout, M.J., 2019. Effects defoliation on the resistance and tolerance of rice, Oryza sativa, to root injury by the rice water weevil, Lissorhoptrus oryzophilus. Entomol. Exp. Appl. 167, 350-359. https://doi.org/10.1111/eea.12789.

Mallapur, C.P., Naik, A.K., Hagari, S., Prabhu, S.T., Patil, P.K., 2018. Status of alien pest fall armyworm, Spodoptera frugiperda (J.E. Smith) on maize in Northern Karnataka. J. Entomol. Zool. Stud. 6, 432-436.

Montezano, D.G., Specht, A., Sosa-Gómez, D.R., Roque-Specht, V.F., SousaSilva, J.C., Paula-Moraes, S.V., Peterson, J.A., Hunt, T.E., 2018. Host plants of Spodoptera frugiperda(Lepidoptera: Noctuidae) in the Americas. Afr. Entomol. 26, 286-300. https://doi.org/10.4001/003.026.0286.

Nascimento, A.M., Assis, F.A., Moraes, J.C., Sakomura, R., 2014. Não preferência a Spodoptera frugiperda (Lepidoptera: Noctuidae) induzida em arroz pela aplicação de silício. Agraria 9, 215-218.

Nascimento, A.M., Assis, F.A., Moraes, J.C., Souza, B.H.S., 2017. Silicon application promotes rice growth and negatively affects development of Spodoptera frugiperda(J. E. Smith). J. Appl. Entomol. 142, 241-249. https://doi.org/10.1111/jen.12461.

Nascimento, J.B., Barrigossi, J.A.F., 2014. Responses of rice mini-core collection accessions to damage by Diatraea saccharalis(Fabricius) stem borer. Agric. Sci. 5, 776-784. https://doi.org/10.4236/as.2014.59082.

Nascimento, J.B., Barrigossi, J.A.F., Borba, T.C.O., Martins, J.F.S., Fernandes, P.M., Mello, R.N., 2015. Evaluation rice genotypes for sugarcane borer resistance using phenotypic methods and molecular markers. Crop Prot. 67, 43-51. https://doi.org/10.1016/j.cropro.2014.09.018.

Negrisoli, A.S., Garcia, M.S., Negrisoli, C.R.C.B., 2010. Compatibility of entomopathogenic nematodes (Nematoda: Rhabditida) with registered insecticides for Spodoptera frugiperda (Smith, 1797) (Lepidoptera: Noctuidae) under laboratory conditions. Crop Prot. 29, 545-549. https://doi.org/10.1016/j.cropro.2009.12.012.

Paiva, L.A., Resende, W.C., Silva, C.L.T., Almeida, A.C.S., Cunha, P.C.R., Jesus, F.G., 2018. Resistance of common bean (Phaseolus vulgaris) cultivars to Spodoptera frugiperda (Lepidoptera: noctuidae). Rev. Colomb. Entomol. 44, 2-18.

Pinto, L.M.N., Fiuza, L.M., Ziegler, D., Oliveira, J.V., Menezes, V.G., Bourrié, I., Meynard, D., Guiderdoni, E., Breitler, J.C., Altosaar, I., Gantet, P., 2013. Indica rice cultivar IRGA 424, transformed with cry genes of $B$. thuringiensis, provided high resistance against Spodoptera frugiperda(Lepidoptera: noctuidae). J. Econ. Entomol. 106, 2585-2594. https://doi.org/10.1603/ec13163.

Pitta, R.M., Boiça Júnior, A.L., Jesus, F.G., Tagliari, S.R., 2010. Seleção de genótipos resistentes de amendoinzeiro a Anticarsia gemmatalis Hübner (Lepidoptera: Noctuidae) com base em análises multivariadas.
Neotrop. Entomol. 39, 260-265. https://doi.org/10.1590/S1519566X2010000200018.

Queiroz, E.B., Miranda, D.S., Silva, F.C., Borella Junior, C., Almeida, A.C.S., Hirose, E., Jesus, F.G., 2020. Antibiosis in soybean genotypes to Spodoptera cosmioides (Lepidoptera: noctuidae). Rev. Bras. Entomol. 64, 20200010. https://doi.org/10.1590/1806-9665-RBENT-2020-0010.

R Core Team, 2017. R: the R project for statistical computing. Version 3.3.3. $R$ Foundation for Statistical Computing, Vienna, Austria.

Ramalho, F.S., Azeredo, T.L., Nascimento, A.R.B., Fernandes, F.S., Nascimento Júnior, J.L., Malaquias, J.B., Silva, C.A.D., Zanuncio, J.C., 2011. Feeding of fall armyworm, Spodoptera frugiperda, on Bt transgenic cotton and its isoline. Entomol. Exp. Appl. 139, 207-214. https://doi. org/10.1111/j.1570-7458.2011.01121.x.

Rashid, A., Khan, J.A., Khan, F.F.J., Hamed, M., 2005. Resistance of different Basmati rice varieties to stem borers under different control tactics of IPM and evaluation of yield. Pak. J. Bot. 37, 319-324.

Scriber, J.M., Slansky Junior, J.R.F., 1981. The nutritional ecology of immature insects. Annu. Rev. Entomol. 26, 183-211.

Seifi, A., Visser, R.G.F., Bai, Y., 2013. How to effectively deploy plant resist- ances to pests and pathogens in crop breeding. Euphytica 190, 321-334. https://doi.org/10.1007/s10681-012-0823-9.

Silva, D.M., Bueno, A.F., Andrade, K., Stecca, C.S., Neves, P.M.O.J., Oliveira, M.C.N., 2017. Biology and nutrition of Spodoptera frugiperda (Lepidoptera: Noctuidae) fed on different food sources. Sci. Agric. 74, 18-31. https://doi.org/10.1590/1678-992x-2015-0160.

Smith, C.M. 2005. Plant resistance to arthropods: molecular and conventional approaches. Springer, Berlin, pp. 423.

Smith, C.M., Clement, S.L., 2012. Molecular bases of plant resistance to arthropods. Annu. Rev. Entomol. 57, 309-328. https://doi.org/10.1146/ annurev-ento-120710-100642.

Sousa, D.M.G., Lobato, E., 2004. Calagem e adubação para culturas anuais e semiperenes. In: Sousa, D.M.G., Lobato, E. (Eds), Cerrado: correção do solo e adubação. 2 ed. Embrapa Informação Tecnológica, Brasília, pp. 283-316.

Stout, M.J., Riggio, M.R., Yang, Y., 2009. Direct induced resistance in Oryza sativa to Spodoptera frugiperda. Environ. Entomol. 38, 1174-1181. https://doi.org/10.1603/022.038.0426.

Ta-Liao, C., Chen, C., 2017. Oviposition preference and larval performance of Cnaphalocrocis medinalis (Lepidoptera: Pyralidae) on rice genotypes. J. Econ. Entomol. 110, 1291-1297. https://doi.org/10.1093/jee/tox071.

Viteri, D.M., Linares, A.M., Flores, L., 2018. Use of the entomopathogenic nematode Steinernema carpocapsae in combination with low-toxicity insecticides to control fall armyworm (Lepidoptera: Noctuidae) larvae. Fla. Entomol. 102, 327-329. https://doi.org/10.1653/024.101.0228.

Waldbauer, G.P., 1968. The consumption and utilization of food by insects. Adv. Insect Physiol. 5, 229-288. https://doi.org/10.1016/ S0065-2806(08)60230-1.

Wang, R., Jiang, C., Guo, X., Chen, D., You, C., Zhang, Y., Wang, M., Li, Q., 2020. Potential distribution of Spodoptera frugiperda (J.E. Smith) in China and the major factors influencing distribution. Glob. Ecol. Conserv. 21, e00865. 